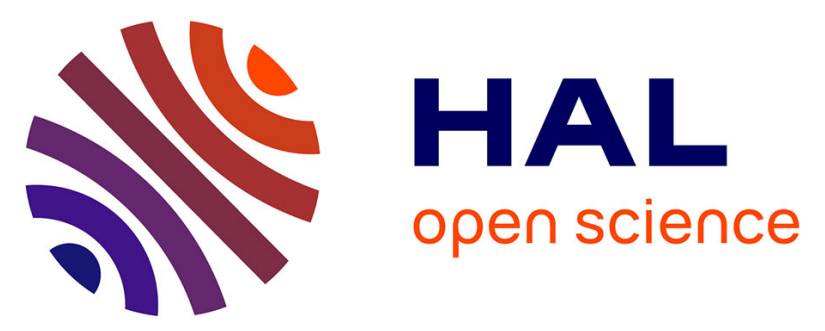

\title{
Polydopamine-coated open cell polyurethane foam as an efficient and easy-to-regenerate soft structured catalytic support (S2CS) for the reduction of dye
}

Louis Lefebvre, Julien Kelber, Loïc Jierry, Vincent Ritleng, David Edouard

\section{- To cite this version:}

Louis Lefebvre, Julien Kelber, Loïc Jierry, Vincent Ritleng, David Edouard. Polydopamine-coated open cell polyurethane foam as an efficient and easy-to-regenerate soft structured catalytic support (S2CS) for the reduction of dye. Journal of Environmental Chemical Engineering, 2017, 5 (1), pp.79 - 85. 10.1016/j.jece.2016.11.025 . hal-01896578

\section{HAL Id: hal-01896578 https://hal.science/hal-01896578}

Submitted on 14 Dec 2021

HAL is a multi-disciplinary open access archive for the deposit and dissemination of scientific research documents, whether they are published or not. The documents may come from teaching and research institutions in France or abroad, or from public or private research centers.
L'archive ouverte pluridisciplinaire HAL, est destinée au dépôt et à la diffusion de documents scientifiques de niveau recherche, publiés ou non, émanant des établissements d'enseignement et de recherche français ou étrangers, des laboratoires publics ou privés. 


\title{
Polydopamine-coated open cell polyurethane foam as an efficient and easy-to-regenerate soft structured catalytic support $\left(S_{2} C S\right)$ for the reduction of dye
}

\author{
Louis Lefebvre $^{\mathrm{a}}$, Julien Kelber ${ }^{\mathrm{b}}$, Lö̈c Jierry ${ }^{\mathrm{b}}$, Vincent Ritleng ${ }^{\text {,dd }}$, David Edouard ${ }^{\mathrm{a} *}$
}

a. Laboratoire d'Automatique et de Génie des Procédés, UMR CNRS 5007, Université de Lyon 1, 43 boulevard du 11 novembre 1918, 69622 Villeurbanne, France.

b. Institut Charles Sadron, UPR CNRS 022, 23 rue du Loess, 67034 Strasbourg, France.

c. Laboratoire de Chimie Organométallique Appliquée, UMR CNRS 7509, Ecole européenne de Chimie, Polymères et Matériaux, Université de Strasbourg, 25 rue Becquerel, 67087 Strasbourg, France.

d. Institut Universitaire de France, 1 rue Descartes, 75231 Paris, France.

* To whom all correspondence should be addressed: E-mail: david.edouard@univ-lyon1.fr

\section{Graphical abstract}

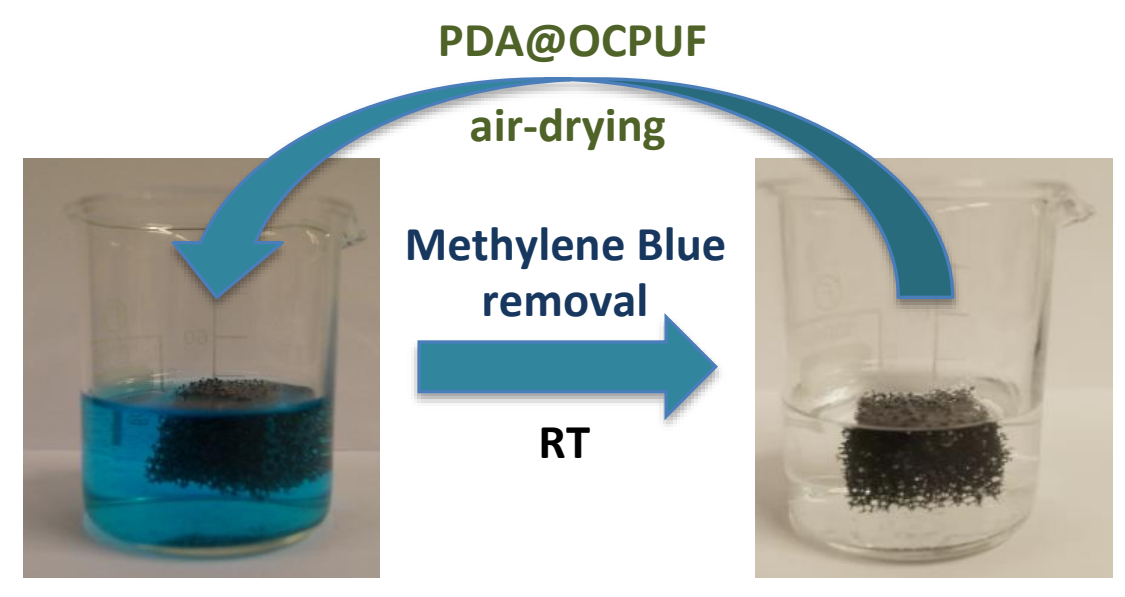

Inexpensive, easy-to-filtrate and easy-to-regenerate!

\begin{abstract}
Commercially available open cell polyurethane foams (OCPUF) are coated with polydopamine (PDA@OCPUF) and used as highly efficient Soft Structured Catalytic Support $\left(\mathrm{S}_{2} \mathrm{CS}\right)$ for the removal of a methylene blue (MB) from aqueous solutions in the presence of sodium borohydride $\left(\mathrm{NaBH}_{4}\right)$. The process relies on the probable dual role of $\mathrm{NaBH}_{4}$ that, on one hand, would allow MB to be adsorbed on the surface of OCPUF by forming an ionic pair, and on the other, would play the role of an electron-donor with the PDA layer acting as an electron relay toward the electron-acceptor dye. The catalytic activity of the PDA layer can be doped with Ag microparticules (MPs) by simple dipping the
\end{abstract}


structured PDA@OCPUF in a solution of silver nitrate. All $\mathrm{S}_{2} \mathrm{CS}$ prepared (OCPUF, PDA@OCPUF and Ag@PDA@OCPUF) were then evaluated and compared. The readily prepared PDA@OCPUF has potential application in wastewater treatment in the presence of $\mathrm{NaBH}_{4}$.

\section{Keywords:}

Polyurethane Open Cell Foam - Polydopamine - Methylene blue - Reduction - Adsorption

\section{Introduction}

Various industrial sectors such as the textile, paper, rubber, plastic, leather, cosmetic, food and drug industries use dyes to color their products [1]. The textile industry, in particular, is one of the biggest producer of dye-containing effluents. Removal of these pigments plays a significant role in wastewater treatment. Indeed dyes, such as methylene blue (MB) which is one of the most commonly used substance for dying cotton, wood and silk [2], interfere with the penetration of sunlight in water, retard photosynthesis, inhibit the growth of aquatic biota, and may be harmful to human health [3].

Various physicochemical methods have been developed to treat these dyes $[4,5,6,7,8,9,10,11,12,13]$. Among these processes, the adsorption technique is widely used in industry owing to its low cost and high removal rates [2,3,5]. The efficiency of an adsorption process is directly linked to the adsorption capacity, availability, cost, and potential for reuse of the chosen adsorbent [14]. Thus, most adsorbents are based on activated charcoal, which is highly efficient and inexpensive. However, because of its powdery nature, it is not a convenient choice for the treatment of high flows. There is therefore a growing demand for low-cost structured materials capable of removing dyes from water. In this context, R. J. Cassella et al. [15] have shown that polyurethane foams (PUF) can be used as an alternative adsorbent of MB in the presence of anionic surfactant; the latter forming a hydrophobic ionic pair with the cationic dye that has a high affinity for PUF. An open cell polyurethane foam (OCPUF; see Fig. 1) approach is exciting since an open cell foam allows an important surface over volume ratio, a small pressure loss (even at high flow) [16,17], efficient mass transfers, an intimate mixing of the reagents $[18,19]$, and an easy separation of the adsorbent (OCPUF) from the solution; no filtration step is required in contrast to powdery adsorbents. Moreover, OCPUF are lightweight structures, commercially available at low cost due to the large variety of applications involving their physical and mechanical properties [20]. 


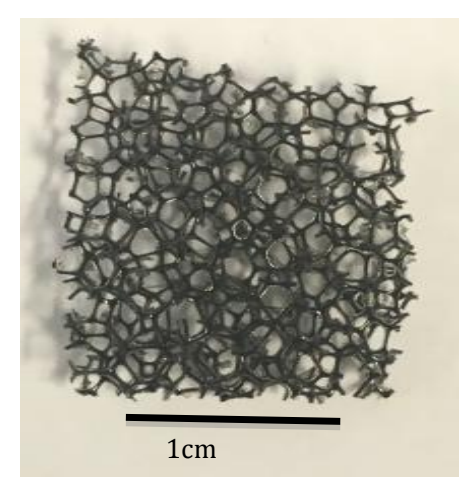

Figure 1. Commercially available polyurethane open cell foam used in this work

The chemical reduction of dyes is also a fast, efficient and commonly used method for water decontamination. In most cases, metal and metal oxide nanoparticles (NPs) are used as redox mediator $(\mathrm{RM})$ catalysts to increase reduction rates in the presence of an electron source (usually an hydride) [21,22,23]. Indeed, RMs are composed of a redox couple with an intrinsically high electron transfer rate, which can assist the interaction between an electron donor and an electron acceptor by acting as an electron relay [23,24,25].

In 2007, Messersmith et al. [26] placed polydopamine (PDA) into the spotlight as a mussel-inspired coating material that can bind to virtually all kinds of inorganic and organic support, including three-dimensional materials such as OCPUF as shown by our recent works $[27,28]$. Furthermore, PDA is known as an environmentally friendly, non-toxic, and efficient redox mediator [29,30]. Thus, PDA possesses numerous catechol groups that are redox-active for a wide range of electrochemical applications [31,32,33,34], and can act as an electron acceptor at neutral and basic $\mathrm{pH}$ values because of the presence of semiquinone and quinone functional groups.

In this context, the work described herein illustrates the concept of Soft Structured Catalytic Support $\left(\mathrm{S}_{2} \mathrm{CS}\right)$ modified by PDA in order to combine the remarkable features of OCPUF (elastic, lightweight, inexpensive) with both the strong adherence and redox properties of PDA. The resulting tool is evaluated for the decontamination of MB-containing wastewater in the presence of $\mathrm{NaBH}_{4}[35.36,37,38]$.

\section{Experimental}

\subsection{Materials and methods}

Commercial compounds were used as received. Dopamine hydrochloride, sodium borohydride, Methylene Blue, Tris base and silver nitrate were purchased from Alfa Aesar. Polyurethane open cell foams (Fig. 1) were purchased from FoamPartner. Their characteristics are as follows: mean strut size: $220 \mu \mathrm{m}$; mean window size: $779 \mu \mathrm{m}$; mean 
cell size: $2500 \mu \mathrm{m}$; density: 0.027-0.033, porosity: 0.94-0.97. Cubic samples of $8 \mathrm{~cm}^{3}$ (180 $\mathrm{mg} \pm 20 \mathrm{mg}$ ) were used without prior treatment. The solutions are prepared with water purified by Synergy® Water Purification System (Millipore).

Polydopamine-coated open cell polyurethane foams (PDA@OCPUF) were prepared according to the reported procedure [27].

Scanning electron microscopy was performed with a Hitachi S800 FEG microscope at the

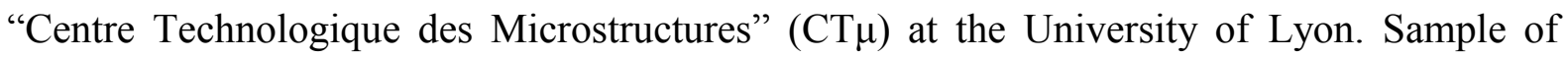
OCPUF, PDA@OCPUF or Ag@PDA@OCPUF was deposited on a flat steel holder and coated under vacuum by cathodic sputtering with platinum. The samples were observed by SEM under an accelerating voltage of $15 \mathrm{kV}$. Elemental analysis was performed with an EDS-SDD detector (SAMx) with an active area of $30 \mathrm{~mm}$.

\subsection{Ag-NPs doping of PDA@OCPUF: preparation of Ag@PDA@OCPUF}

A cubic sample of PDA@OCPUF $\left(8 \mathrm{~cm}^{3}\right)$ was immersed for $24 \mathrm{~h}$ at room temperature in a stirred aqueous solution $(50 \mathrm{~mL})$ of $\mathrm{AgNO}_{3}(0.425 \mathrm{~g}, 50 \mathrm{mM})$ in the dark. The resulting Ag-functionalized open cell foam (Ag@PDA@OCPUF) was then taken out of the solution, rinsed thoroughly with water, immersed in vigorously stirred water $(70 \mathrm{~mL})$ for $10 \mathrm{~min}$, and air-dried. This washing procedure was repeated 5 times, and Ag@PDA@OCPUF was finally dried overnight in an oven at $67^{\circ} \mathrm{C}$.

Ag@PDA@OCPUF materials were characterized by SEM micrographs combined to energy dispersive X-ray spectroscopy (EDX). The mass of Ag NPs immobilized on PDA@OCPUF was estimated to be of $c a .3 \mathrm{mg}$ by simply weighing the foams before after silver doping.

\subsection{General procedure for the removal of methylene blue in water}

In a typical experiment, an aqueous solution of $\mathrm{MB}\left(50 \mathrm{~mL}, 2.10^{-5}-5.10^{-5} \mathrm{M}\right)$ was stirred at room temperature $(500-700 \mathrm{rpm})$ in the presence of $\mathrm{NaBH}_{4}(945 \mathrm{~g} / 250 \mathrm{~mL}, 0.1 \mathrm{M})$ and of cubic sample $\left(8 \mathrm{~cm}^{3}\right)$ of OCPUF, PDA@OCPUF or Ag@PDA@OCPUF. The disappearance of MB was followed by measuring the decrease of its absorbance peak at $664 \mathrm{~nm}$ in the UVvisible spectra of the reaction solution in function of the time of reaction. The percentage of MB removed from the solution was calculated according to equation (1):

$$
\mathrm{R}(\%)=100 \times[1-(\mathrm{C}(t) / \mathrm{C}(0)]
$$

where $R$ is the removal percentage, $C(0)$ the initial concentration of $\mathrm{MB}$ in the solution, and $C(t)$ the concentration in the solution at time $t$. 
Between two successive runs, the foam was taken out of the reaction medium, washed with Milli-Q water and re-immerged in a fresh solution of $\mathrm{MB}$ and $\mathrm{NaBH}_{4}$.

\section{Results and discussion}

\subsection{Preparation and characterization of PDA@OCPUF}

PDA@OCPUF were prepared by simple immersion of cubic samples of OCPUF at room temperature in an aqueous solution of dopamine buffered to a $\mathrm{pH}$ of 8.5 (Fig. 2), followed by thorough washings with water, according to our recently reported procedure [27]. Similarly to this work, low magnification scanning electron microscopy (SEM) images of PDA@OCPUF (Fig. $2-20 \mu \mathrm{m}$ scale) revealed a coating of PDA on the whole surface of the 3D material at a macroscopic level. However, higher magnification SEM image (Fig. 2b - 2 $\mu \mathrm{m}$ scale) highlighted a rough film with the presence of dispersed aggregates as typically observed on flat surfaces [39]. The mass of PDA on a $8 \mathrm{~cm}^{3}$ sample of OCPUF was evaluated to be of $c a .2 \mathrm{mg} \pm 0.5 \mathrm{mg}$.
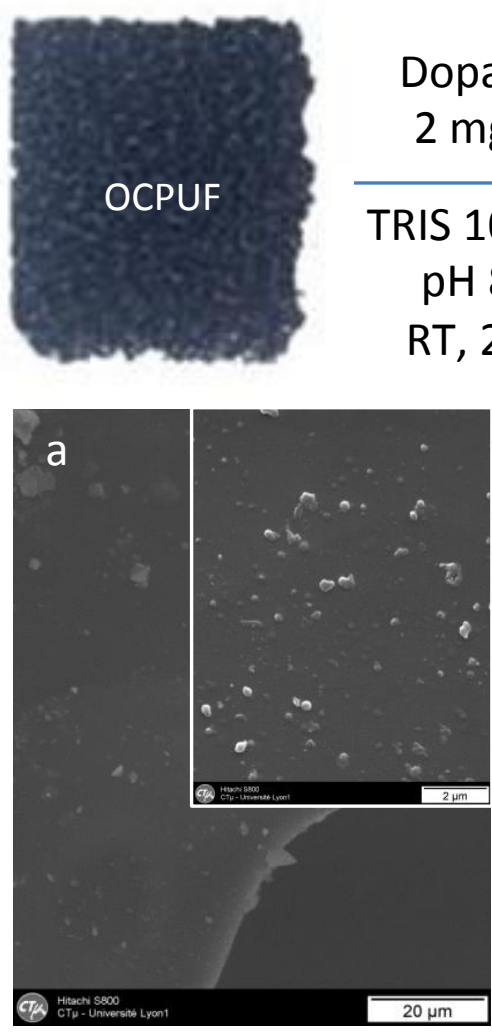
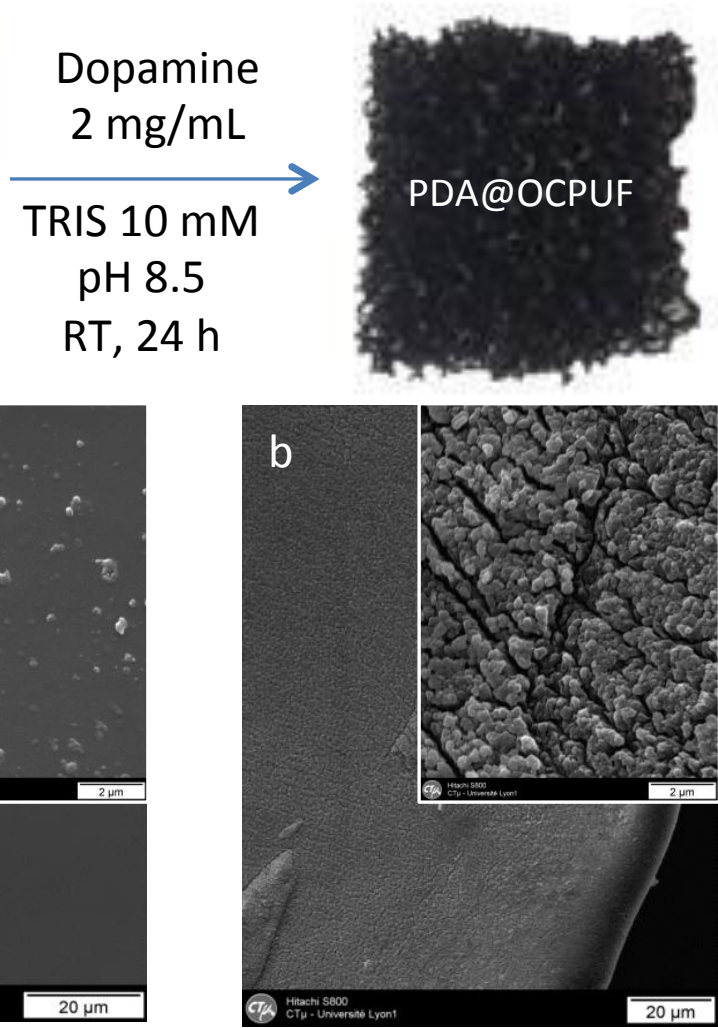

Figure 2. OCPUF coating with PDA (up), and SEM images of OCPUF (a) and PDA@OCPUF (b) (down) 
The activity of these PDA-coated foams were then evaluated and compared to that of uncoated OCPUF for the adsorption/reduction of MB in water. Experiments were conducted by simply immerging a sample of OCPUF or PDA@OCPUF in a stirred aqueous solution of MB $\left(2.10^{-5} \mathrm{M}\right)$ in the presence (or in the absence) of $\mathrm{NaBH}_{4}$ as a hydride source (Fig. 3). The adsorption/reduction of MB was followed by the measure of the decrease of its absorbance peak at $664 \mathrm{~nm}$ in the UV-visible spectrum of the reaction medium. After a given time (25 $\mathrm{min}$ ), the foams were reused by re-immersion in fresh solutions of $\mathrm{MB}$ and $\mathrm{NaBH}_{4}$. In Figure 4, we show the percentage of MB adsorbed and/or reduced on the support with OCPUF (a) and PDA@OCPUF (b) in function of the reaction time.
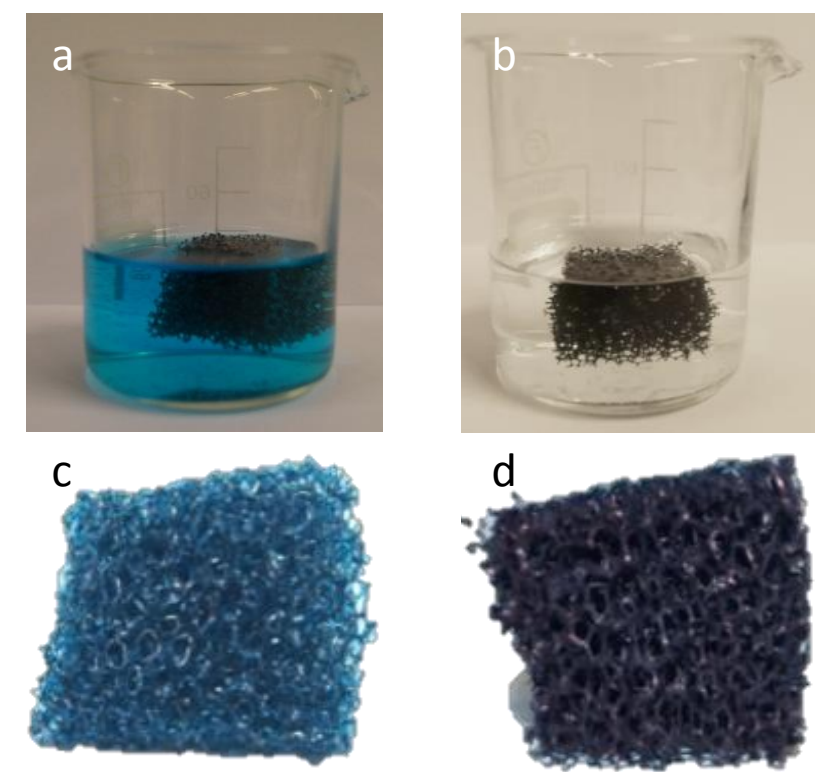

Figure 3. Degradation/removal of MB with OCPUF and PDA@OCPUF: solution and foam color after 3 runs with OCPUF (a, c) and after 5 runs with PDA@OCPUF (b, d)
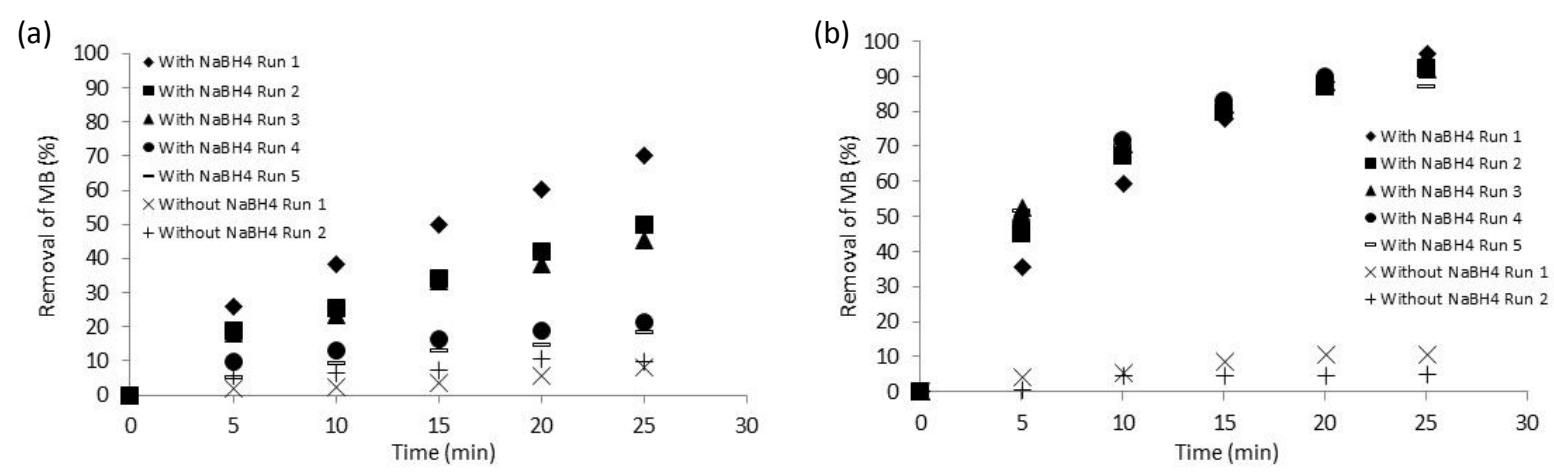

Figure 4. Percentage of MB removal $\left(50 \mathrm{~mL}, 2.10^{-5} \mathrm{M}\right)$ in function of time: (a) with OCPUF, (b) with PDA@OCPUF. $\left[\mathrm{NaBH}_{4}\right]=0.1 \mathrm{M}$ 
In the case of non-coated OCPUF (Fig. 4a), negligible disappearance of MB was observed after $25 \mathrm{~min}$ in the absence of $\mathrm{NaBH}_{4}$, most probably in reason of the weak affinity of $\mathrm{MB}$ for polyurethane. In contrast, in the presence of a high concentration of $\mathrm{NaBH}_{4}\left(0.1 \mathrm{M}\right.$ vs. $2.10^{-5}$ $\mathrm{M}$ of $\mathrm{MB}$ ), about $70 \%$ of $\mathrm{MB}$ had been removed after $25 \mathrm{~min}$ (run 1). The amount of MB that was removed, however, decreased to $c a$. $50 \%$ in run 2, $40 \%$ in run 3, and $20 \%$ in run 4 (Fig. 4a). These results strongly suggest that a simple adsorption phenomenon occurs in these conditions. Thus, the amount of removed MB would dramatically decrease after 3 runs simply because the surface of OCPUF is saturated and the maximum adsorption capacity of MB has been reached (see the color of the OCPUF after 3 runs, Fig 3c). Similar results were observed by R. J. Cassella et al. [15] for the adsorption of MB on PUF in the presence of sodium dodecylsulfate, the latter presumably forming an ionic pair with MB that would be the substance sorbed onto PUF. Hence, we assume that a similar phenomenon would occur here, with the ionic pair formed from the cationic dye and $\mathrm{BH}_{4}{ }^{-}$being sorbed onto our OCPUF.

In the case of PDA@OCPUF also, negligible disappearance of MB was observed in the absence of $\mathrm{NaBH}_{4}$ (Fig. 4b), thus showing that the presence of PDA on the OCPUF surface does not significantly affect the adsorption of $\mathrm{MB}$ onto polyurethane. However, in the presence of a high concentration of $\mathrm{NaBH}_{4}\left(0.1\right.$ mol.L $\left.\mathrm{L}^{-1}\right)$, complete removal of $\mathrm{MB}$ was observed within $25 \mathrm{~min}$ (Fig. 4b, run 1), and the PDA-coated open cell foam could be reused at least 5 times with an almost constant activity (Fig. 4b, runs 2 to 5). This is in agreement with the recent work of F. Zuo et al.[30], which has shown that PDA microparticles (MPs) have only little effect on the decolorization of $\mathrm{MB}$ in the absence of $\mathrm{NaBH}_{4}$, but can act as a good catalyst for the reduction of $\mathrm{MB}$ by $\mathrm{NaBH}_{4}$.

Based on these results and on those obtained with uncoated OCPUF, as well as on the above cited literature precedents $[15,30]$, we believe that $\mathrm{NaBH}_{4}$ plays a dual role here: on one hand $\mathrm{BH}_{4}{ }^{-}$would allow MB to be adsorbed on the surface of OCPUF by forming an ionic pair, and on the other, it would play the role of an electron-donor with the PDA layer acting as an electron relay toward the electron-acceptor dye (Scheme 1). Although being thermodynamically favorable, the reduction of $\mathrm{MB}$ with $\mathrm{NaBH}_{4}$ is indeed kinetically restricted in the absence of a catalyst (or redox mediator) [30], as confirmed by the absence of decolorization of $\mathrm{MB}$ by $\mathrm{NaBH}_{4}$ in the absence of PDA@ OCPUF (Fig. 5). 


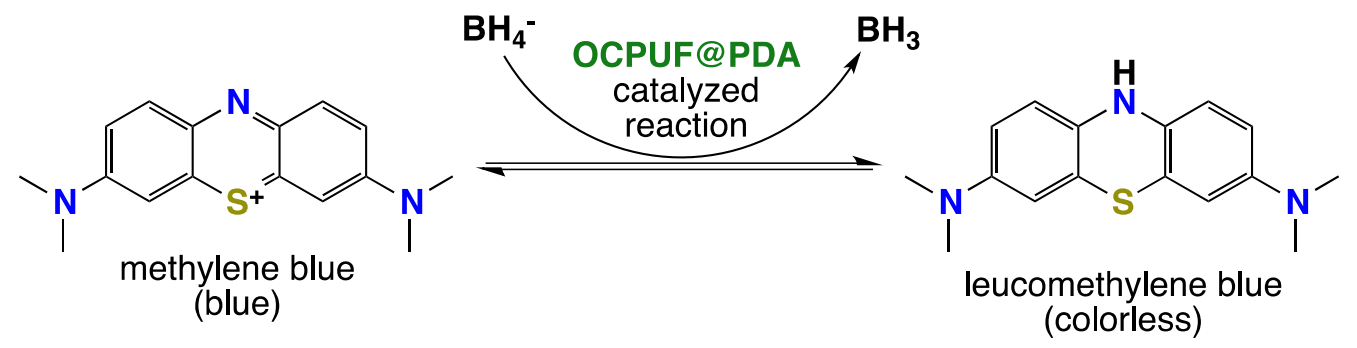

Scheme 1. OCPUF@PDA-catalyzed reduction of MB by $\mathrm{NaBH}_{4}$

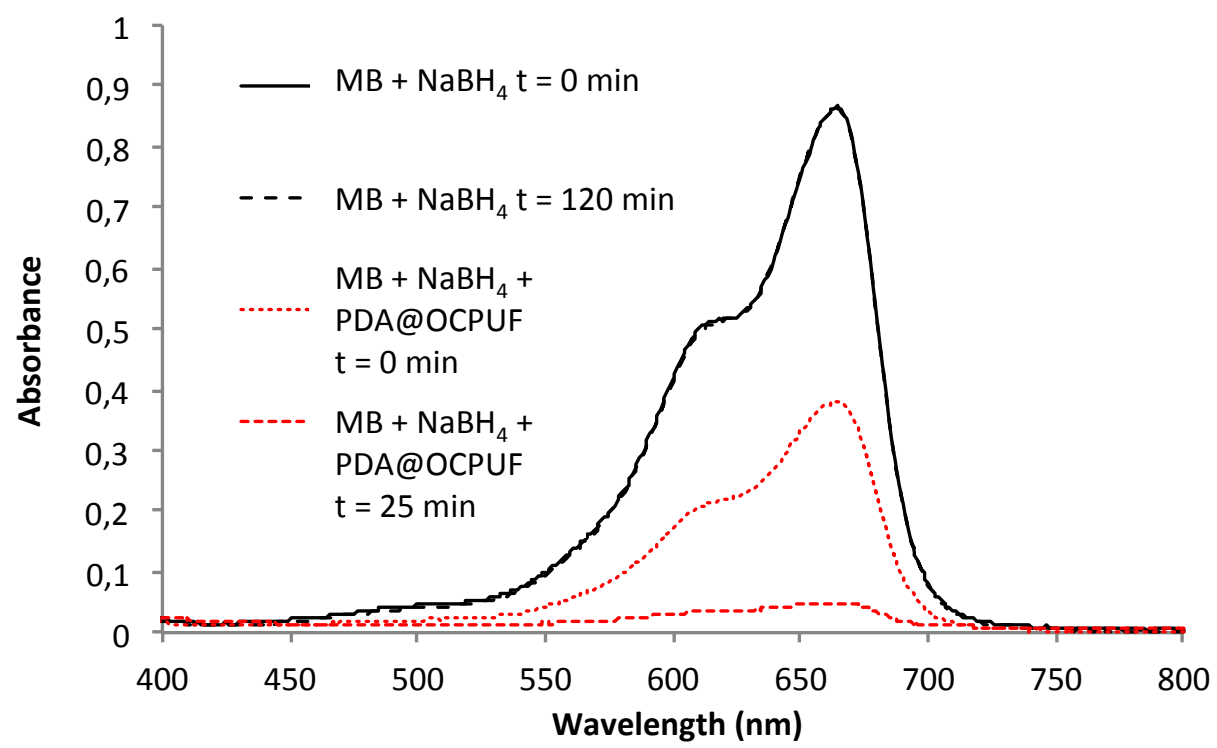

Figure 5. UV-Vis spectra of aqueous solutions of $\mathrm{MB}\left(2.10^{-5} \mathrm{M}\right)$ and $\mathrm{NaBH}_{4}(0.1 \mathrm{M})$ in the absence and in the presence of PDA@OCPUF after various reaction times

For the PDA@OCPUF samples, the catalytic activity can be then quantitatively estimated. As the initial concentration of $\mathrm{NaBH}_{4}$ was in large excess compared to that of $\mathrm{MB}$, pseudofirst order reaction kinetics can be applied. Considering a simplified model, the concentration evolution $(C(t))$ of $\mathrm{BM}$ can be given by the following relations:

$$
\begin{aligned}
& \left\{\begin{array}{l}
\frac{d C(t)}{d t}=-v_{a d s}+v_{d e s}-v_{P D A} \\
\frac{d C_{a d s}(t)}{d t}=v_{a d s}-v_{d e s}-v_{P D A}
\end{array}\right. \\
& v_{a d s}=k_{a d s}[C(t)], \quad v_{d e s}=k_{d e s}\left[C_{a d s}(t)\right], \quad v_{P D A}=k_{P D A}\left[C_{a d s}(t)\right]
\end{aligned}
$$

with $C(t)$ and $C_{a d s}(t)$ being the concentration of $\mathrm{MB}$ in the solution and that adsorbed on the open cell foam, respectively, and $k_{a d s}$ (adsorption constant) and $k_{d e s}$ (desorption constant) being directly obtained from the adsorption measurement with OCPUF sample (Fig. 6). 


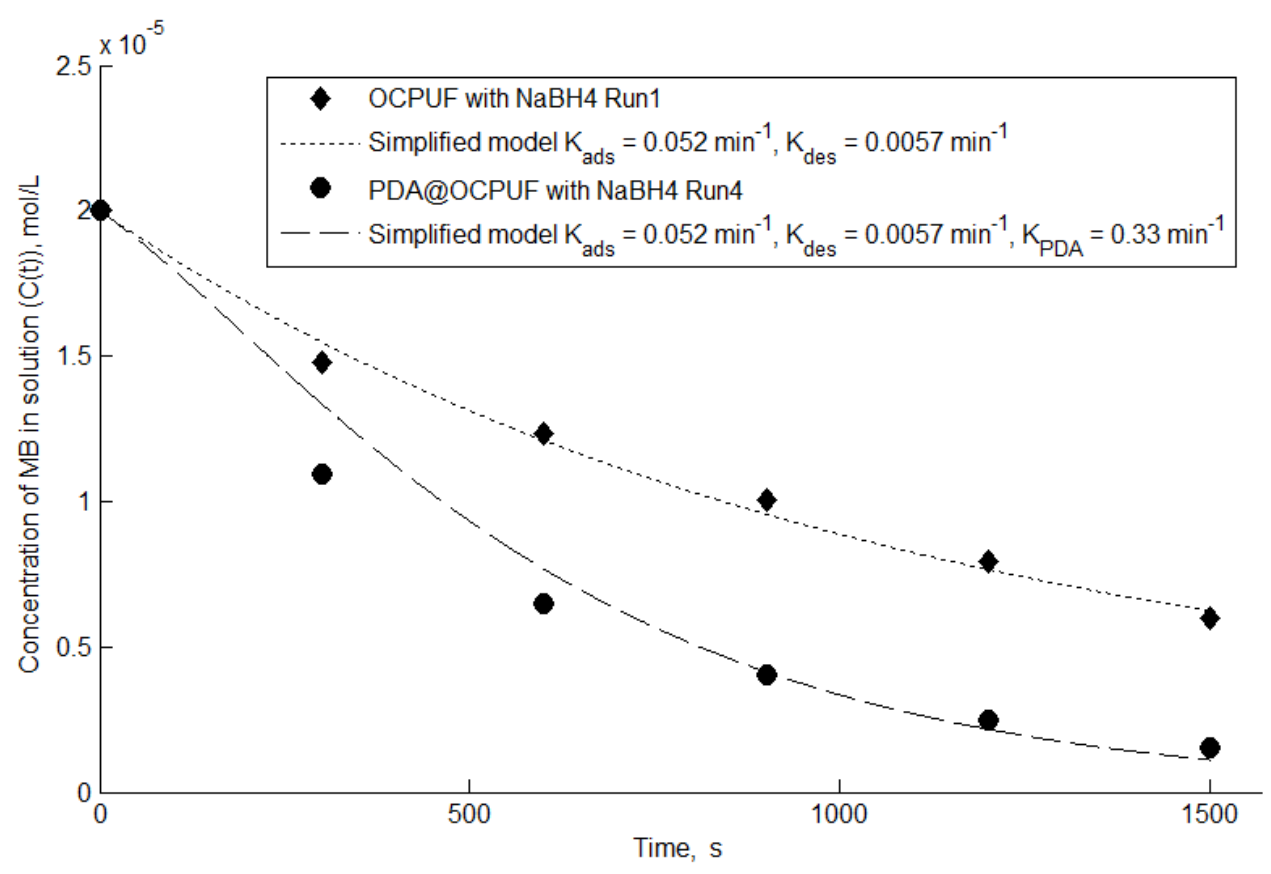

Figure 6. Kinetic simplified model $v s$. experiments

In a first approximation, the agreement between the experimental values and the simplified model is satisfying in order to estimate the catalytic activity of the PDA layer. The best fit for the apparent rate constant of PDA $\left(k_{P D A}\right)$ was found to be $0.33 \mathrm{~min}^{-1}$, which is in very good agreement with the value of $0.328 \mathrm{~min}^{-1}$ found for the activity of unsupported PDA microparticles [30].

\subsection{Stability and recyclability of the soft structured PDA@OCPUF}

From an industrial point of view, the stability and recyclability of a catalytic material are key features. In this context, based on work of the F. Zuo et al. [30], which demonstrated (i) that quinone groups such as those of anthraquinone-2-sulfonate accelerate the electron transfer between $\mathrm{NaBH}_{4}$ and $\mathrm{MB}$, (ii) that the decrease in quinone content of PDA MPs (probably owing to an incomplete reduction/oxidation cycle between quinones and catechols during the electron transfer process) was the main reason for their deactivation, and (iii) that the quinone content, and hence the activity, of the PDA MPs can be increased by oxidation with $\mathrm{NaIO}_{4}$, we present here a simple procedure, i.e. air re-oxidation at room temperature, in order to ensure recyclability of our soft structured redox mediator catalyst, PDA@OCPUF.

Indeed, similarly to what was observed with PDA MPs, the removal rate of MB gradually decreased during the successive runs conducted with PDA@OCPUF (Fig. 4). Assuming that this was also due to a decrease of the amount of quinone moieties, we decided to attempt to re-oxidize the resulting catechol groups by simple exposure of the foams to air. Gratifyingly 
after $8 \mathrm{~h}$ exposure at $67{ }^{\circ} \mathrm{C}$, the activity re-increased from $31 \%$ removal after $25 \mathrm{~min}$ in run 10 to $\mathrm{ca}$. $50 \%$ removal in run 11, but decreased again quickly in runs 12 and 13 (Fig. 7a). Novel exposure to air for then 6 days at room temperature between run 13 and 14 proved even more efficient since the activity of re-oxidized PDA@OCPUF was this time almost quantitatively recovered with over $81 \%$ removal of $\mathrm{MB}$ after $25 \mathrm{~min}$ ( $v s .91 \%$ removal in run 1), and then decreased gradually in the successive runs (see Fig. 7b, run 13 to 18) at a rate similar to that observed in the first runs. These results unambiguously indicate that a dynamic equilibrium exists between quinone and catechol, and thus that the PDA@OCPUF RM can be efficiently regenerated by simple exposure to air at room temperature for several days.

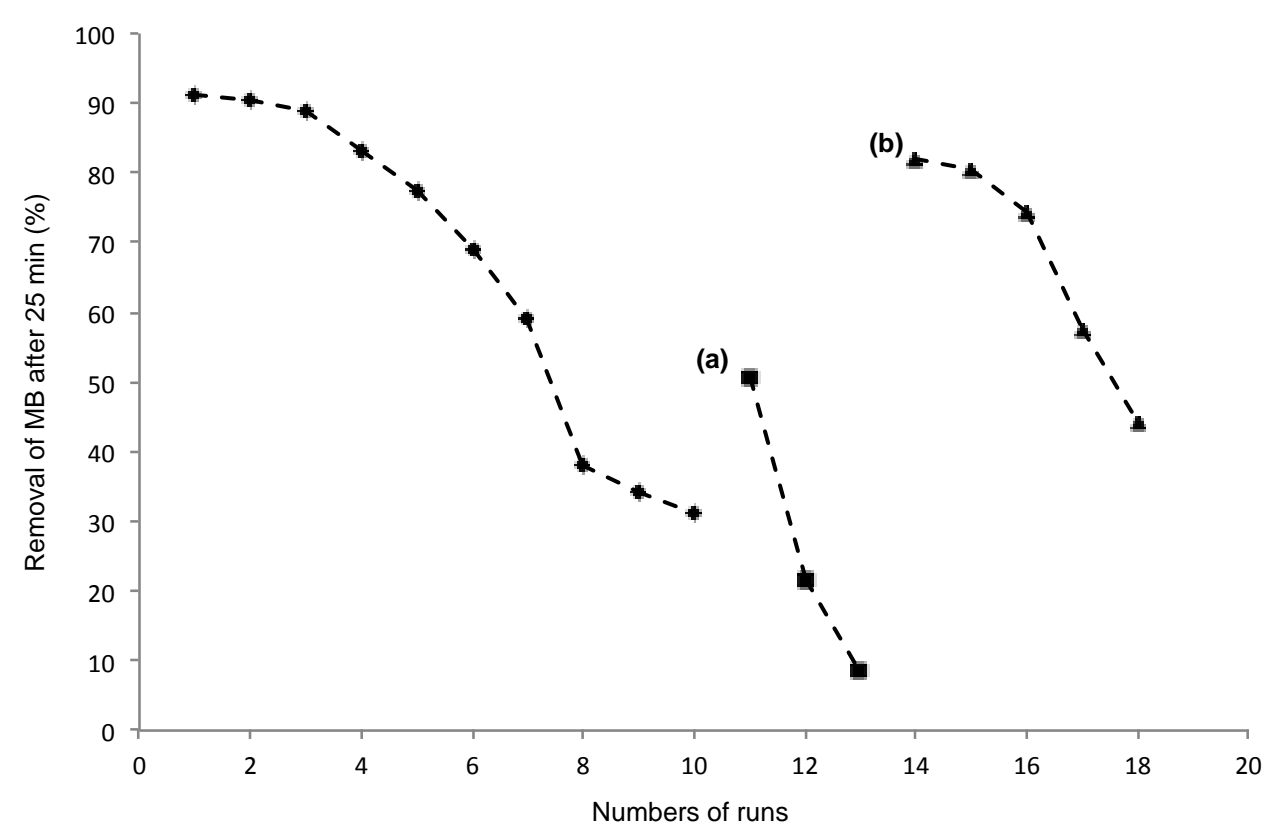

Figure 7. Recyclability of the PDA@OCPUF by simple exposure to air: (a) for $8 \mathrm{~h}$ at $67{ }^{\circ} \mathrm{C}$, (b) for 6 days at RT. $[\mathrm{MB}]=5.10^{-5} \mathrm{M},\left[\mathrm{NaBH}_{4}\right]=0.1 \mathrm{M}$, PDA@ OCPUF: $\mathrm{m}=173 \mathrm{mg}(0.5$ mg PDA).

3.4. Silver NPs doping of the soft structured PDA@OCPUF redox mediator: catalytic activityofAg@PDA@OCPUF

The ability of PDA to reduce some noble metal ions such as $\mathrm{Ag}^{+}$is well known [40]. This property has been used recently to prepare uniformly distributed multilayer Ag NPs on the surface of a PDA-coated polyethylene film by simple alternative immersion in silver nitrate and dopamine solutions [41]. The obtained material demonstrated interesting catalytic activity for the decoloration of $\mathrm{MB}$ in the presence of $\mathrm{NaBH}_{4}$.

On this basis, we doped our structured PDA@OCPUF redox mediator with Ag NPs by simple dipping a sample in a stirred $50 \mathrm{mM}$ silver nitrate solution for $24 \mathrm{~h}$ at room 
temperature (Fig. 8a). The presence of Ag NPs on the obtained Ag@PDA@OCPUF material was confirmed by SEM micrographs combined to energy dispersive X-ray spectroscopy (EDX) (Fig 8b and 8c). The SEM images showed that the Ag NPs were not uniformly distributed but were rather present as nanometric clusters $(30-50 \mathrm{~nm})$ randomly dispersed all over the surface of the modified 3D material, similarly to what we observed with $\mathrm{TiO}_{2}$ NPs in previous works [27,28]. The mass of Ag NPs immobilized on PDA@OCPUF was estimated to be of $c a .3 \mathrm{mg}$ by simply weighing the foams before after silver doping.

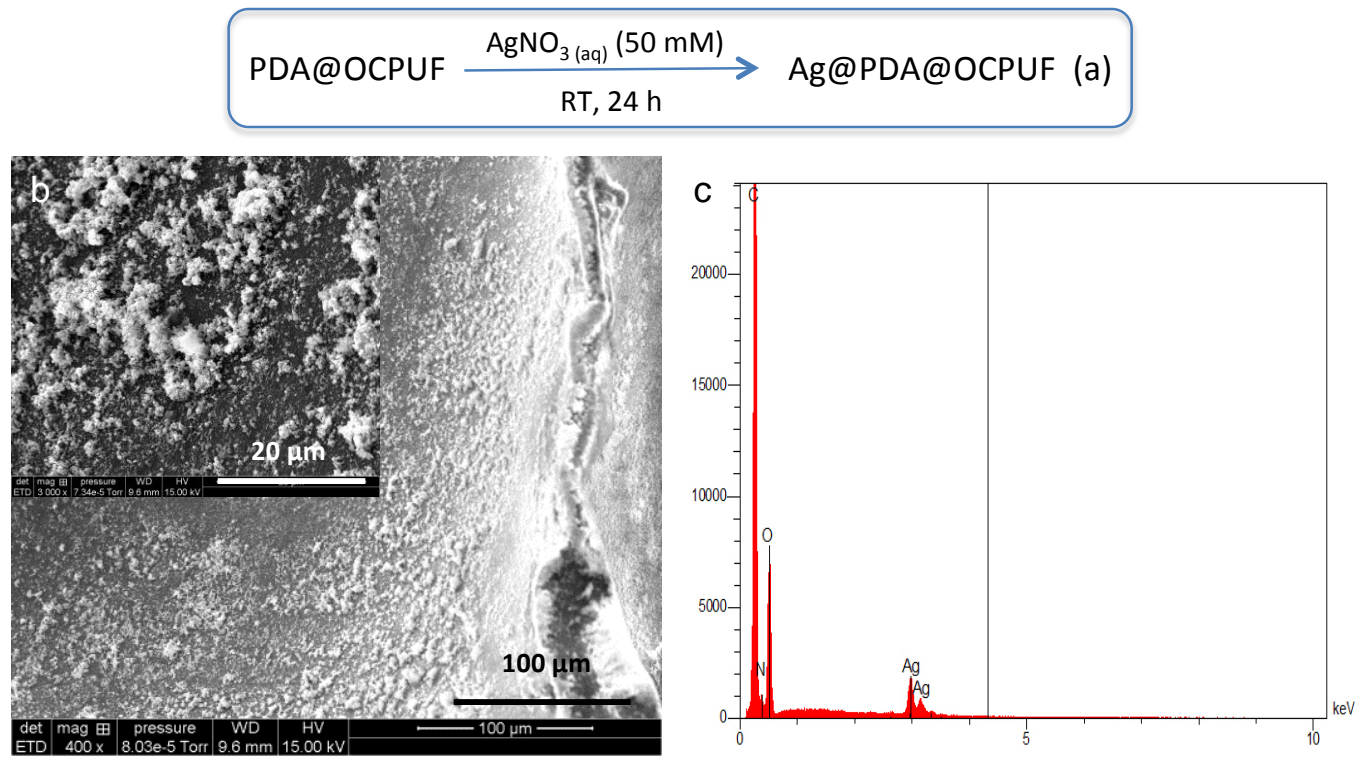

Figure 8. PDA@ OCPUF doping with Ag NPs (a), SEM images of Ag@PDA@ OCPUF (b), and the EDX spectra (c)

The activity of these soft structured catalytic Ag@PDA@OCPUF materials were then evaluated and compared to that of uncoated OCPUF and PDA@OCPUF for the adsorption/reduction of $\mathrm{MB}$ in water. Experiments were conducted similarly than for the latter. As can be seen from Fig. 9, a net beneficial effect of Ag NPs on the removal of the MB was observed. Thus, over 95\% removal of MB was observed after 25 min for 6 consecutive runs. Moreover, until the third run, the use of Ag@PDA@OCPUF led to about 90\% decontamination after only $15 \mathrm{~min}$ instead of $25 \mathrm{~min}$ for PDA@OCPUF. From run 4 to 6 , the rate of MB decontamination observed with Ag@PDA@OCPUF became however similar to that observed with PDA@OCPUF, which may suggest a deactivation of the Ag NPs at this stage. 


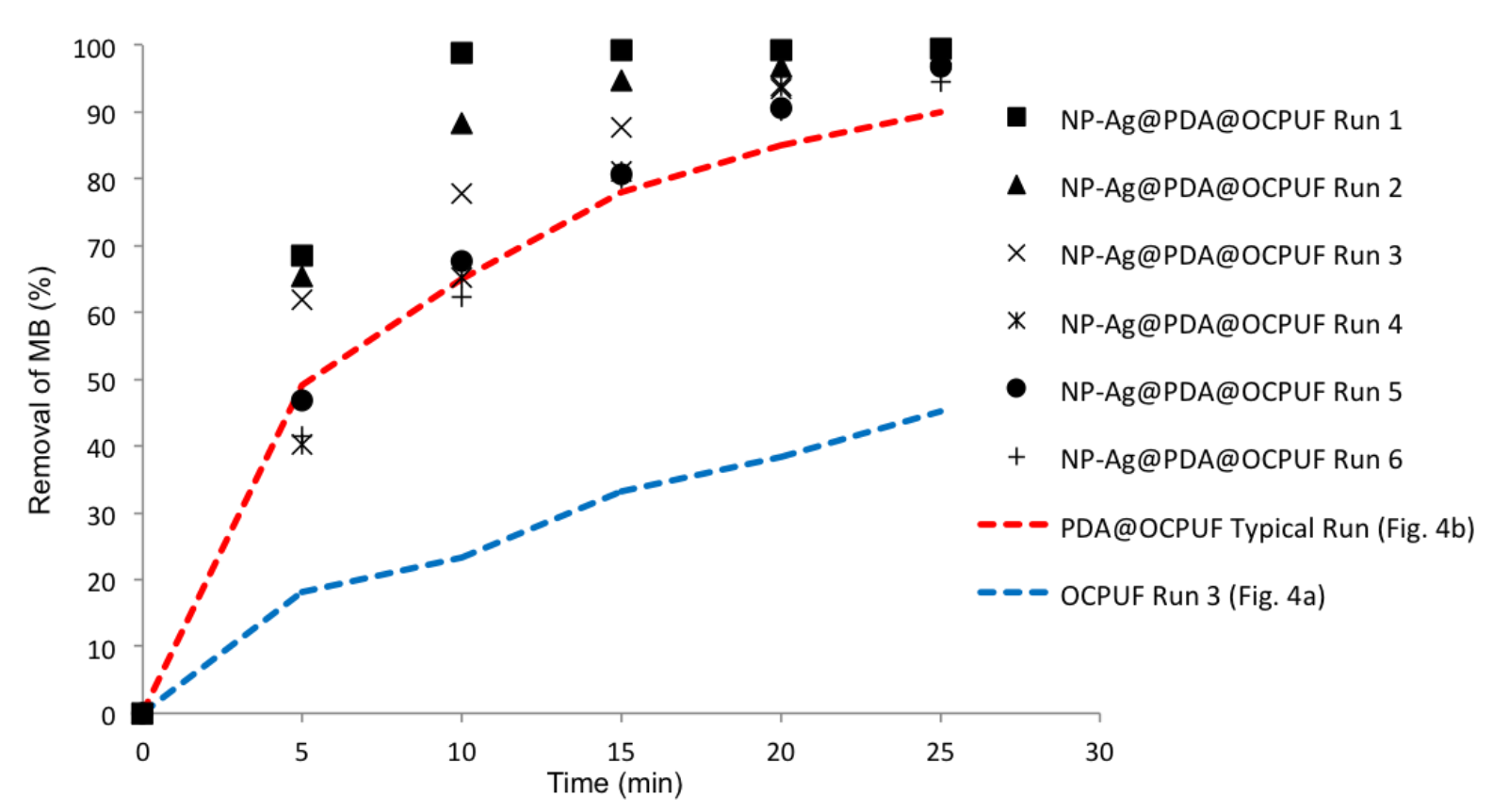

Figure 9. Percentage of $\mathrm{MB}$ removal $\left(50 \mathrm{~mL}, 2.10^{-5} \mathrm{M}\right)$ in function of time with Ag@PDA@OCPUF. $\left[\mathrm{NaBH}_{4}\right]=0.1 \mathrm{M}$

\section{Conclusion}

In summary, we have demonstrated that our recently introduced Soft Structured Catalytic Support $\left(\mathrm{S}_{2} \mathrm{CS}\right)[27,28]$ based on a bioinspired coating of OCPUF by PDA is an efficient support for the reduction of dye. The thin film of PDA onto the OCPUF surface provides RM properties to the open cell foam. Moreover, the RM properties of the PDA@OCPUF $\mathrm{S}_{2} \mathrm{CS}$ can be efficiently regenerated by simple exposure to air at room temperature. Finally, it is possible to dope the catalytic activity of the $\mathrm{S}_{2} \mathrm{CS}$ after immobilization of Ag NPs on the PDA@OCPUF's surface by simple dipping in a $\mathrm{AgNO}_{3}$ solution. In conclusion, the strategy presented in this work provides a facile, green approach towards designing Soft Structured Catalytic Supports for biological and environmental applications.

\section{Acknowledgements}

We are grateful to the University of Lyon 1 for financial support.

\section{References}

[1] C.I. Pearce, J.R. Lloyd, J.T. Guthrie, The removal of colour from textile wastewater using whole bacterial cells: a review, Dyes Pigments 58 (2003) 179-196.

[2] M. Rafatullah, O. Sulaiman, R. Hashim, A. Ahmad, Adsorption of methylene blue on low-cost adsorbents: A review, J. Hazard. Mater. 177 (2010) 70-80. 
[3] A.T. Paulino, M.R. Guilherme, A.V. Reis, G.M. Campese, E.C. Muniz, J. Nozaki, Removal of methylene blue dye from an aqueous media using superabsorbent hydrogel supported on modified polysaccharide, J. Colloid Interface Sci. 301 (2006) 55-62.

[4] V.K. Gupta, I. Ali, T.A. Saleh, A. Nayak, S. Agarwal, Chemical treatment technologies for waste-water recycling — an overview, RSC Adv. 2 (2012) 6380-6388.

[5] I. Ali, New Generation Adsorbents for Water Treatment, Chem. Rev. 112 (2012) 50735091 .

[6] T.A. Kurniawan, G.Y.S. Chan, W.-H. Lo, S. Babel, Physico-chemical treatment techniques for wastewater laden with heavy metals, Chem. Eng. J. 118 (2006) 83-98.

[7] P. Le-Clech, V. Chen, T.A.G. Fane, Fouling in membrane bioreactors used in wastewater treatment, J. Membr. Sci. 284 (2006) 17-53.

[8] V. López-Grimau, M.C. Gutiérrez Decolourisation of simulated reactive dyebath effluents by electrochemical oxidation assisted by UV light, Chemosphere 62 (2006) 106-112.

[9] P.R. Gogate, A.B. Pandit, A review of imperative technologies for wastewater treatment I: oxidation technologies at ambient conditions, Adv. Environ. Res. 8 (2004) $501-551$.

[10] P.R. Gogate, A.B. Pandit, A review of imperative technologies for wastewater treatment II: hybrid methods, Adv. Environ. Res. 8 (2004) 553-597.

[11] B. Cui, H. Peng, H. Xia, X. Guo, H. Guo, Magnetically recoverable core-shell nanocomposites $\gamma-\mathrm{Fe}_{2} \mathrm{O}_{3} @ \mathrm{SiO}_{2} @ \mathrm{TiO}_{2}-\mathrm{Ag}$ with enhanced photocatalytic activity and antibacterial activity, Sep. Purif. Technol. 103 (2013) 251-257.

[12] V. Prigione, I. Grosso, V. Tigini, A. Anastasi, G.C. Varese, Fungal waste-biomasses as potential low-cost biosorbents for decolorization of textile wastewaters, Water 4 (2012) $770-784$.

[13] M. Zaied, E. Chutet, S. Peulon, N. Bellakhal, B. Desmazières, M. Dachraoui, A. Chaussé, Spontaneous oxidative degradation of indigo carmine by thin films of birnessite electrodeposited onto $\mathrm{SnO}_{2}$, Appl. Catal. B: Environ. 107 (2011) 42-51.

[14] S.A. Figueiredo, R.A. Boaventura, J.M. Loureiro Color removal with natural adsorbents: modeling, simulation and experimental, Sep. Purif. Technol. 20 (2000) $129-141$.

[15] E.E. Baldez, N.F. Robaina, R.J. Cassella, Employment of polyurethane foam for the adsorption of Methylene Blue in aqueous medium, J. Hazard. Mater. 159 (2008) 580586. 
[16] D. Edouard, M. Lacroix, C. Pham Huu, F. Luck, Pressure drop modeling on SOLID foam: state-of-the art correlation Chem. Eng. J. 144 (2008) 299-311.

[17] T. Truong Huu, M. Lacroix, C. Pham Huu, D. Schweich, D. Edouard, Towards a more realistic modeling of solid foam: use of the pentagonal dodecahedron geometry, Chem. Eng. Sci. 64 (2009) 5131-5142.

[18] J.T. Richardson, D. Remue., J.-K. Hung, Properties of ceramic foam catalyst supports: mass and heat transfer, Appl. Catal. A: Gen. 250 (2003) 319-329.

[19] L. Giani, G. Groppi, E. Tronconi, Mass-transfer characterization of metallic foams as supports for structured catalysts, Ind. Eng. Chem. Res. 44 (2005) 4993-5002.

[20] H.-W. Engels, H.-G. Pirkl, R. Albers, R.W. Albach, J. Krause, A. Hoffmann, H. Casselmann, J. Dormish, Polyurethanes: Versatile Materials and Sustainable Problem Solvers for Today's Challenges, Angew. Chem. Int. Ed. 52 (2013) 9422-9441.

[21] W. Peng, F. Zhang, G. Zhang, B. Liu, X. Fan, Selective reduction of 4,4'dinitrostilbene-2,2'-disulfonic acid catalyzed by supported nano-sized gold with sodium formate as hydrogen source, Catal. Commun. 12 (2011) 568-572.

[22] Y. Li, Y. Cao, J. Xie, D. Jia, H. Qin, Z. Liang, Facile solid-state synthesis of Ag/graphene oxide nanocomposites as highly active and stable catalyst for the reduction of 4-nitrophenol, Catal. Commun. 58 (2015) 21-25.

[23] M.M. Khan, J. Lee, M.H. Cho, Au@ $\mathrm{TiO}_{2}$ nanocomposites for the catalytic degradation of methyl orange and methylene blue: An electron relay effect, J. Ind. Eng. Chem. 20 (2014), 1584-1590.

[24] Z. Xi, J. Guo, J. Lian, H. Li, L. Zhao, X. Liu, C. Zhang, J. Yang, Study the catalyzing mechanism of dissolved redox mediators on bio-denitrification by metabolic inhibitors, Bioresour. Technol. 140 (2013) 22-27.

[25] H. Lu, H. Zhang, J. Wang, J. Zhou, Y. Zhou, A novel quinone/reduced graphene oxide composite as a solid-phase redox mediator for chemical and biological Acid Yellow 36 reduction, RSC Adv. 4 (2014) 47297-47303.

[26] H. Lee, S.M. Dellatore, W.M. Miller, P.B. Messersmith, Mussel-Inspired Surface Chemistry for Multifunctional Coatings, Science 318 (2007) 426-430.

[27] E. Pardieu, N.T.T. Chau, T. Dintzer, T. Romero, D. Favier, T. Roland, D. Edouard, L. Jierry, V. Ritleng, Polydopamine-coated open cell polyurethane foams as an inexpensive, flexible yet robust catalyst support: a proof of concept, Chem. Commun. 52 (2016) 4691-4693. 
[28] D. Edouard, V. Ritleng, L. Jierry, N.T.T. Chau Dalencon, Process of modification of the surface properties of cellular elastomeric foams, WO 2016012689 A2 (2016).

[29] J.H. Kim, M. Lee, C.B. Park, Polydopamine as a Biomimetic Electron Gate for Artificial Photosynthesis, Angew. Chem. Int. Ed. 53 (2014) 6364-6368.

[30] S. Du, Z. Liao, Z. Qin, F. Zuo, X. Li, Polydopamine microparticles as redox mediators for catalytic reduction of methylene blue and rhodamine B, Catal. Commun. 72 (2015) 86-90.

[31] Y. Tan, W. Deng, Y. Li, Z. Huang, Y. Meng, Q. Xie, M. Ma, S. Yao, Polymeric bionanocomposite cast thin films with in situ Laccase-catalyzed polymerization of dopamine for biosensing and biofuel cell applications, J. Phys. Chem. B 114 (2010) 5016-5024.

[32] M.-H. Ryou, D.J. Lee, J.-N. Lee, Y. M. Lee, J.-K. Park, J.W. Choi, Excellent cycle life of lithium-metal anodes in lithium-ion batteries with mussel-inspired polydopaminecoated separators, Adv. Energy Mater. 2 (2012) 645-650.

[33] T.-T. Zheng, R. Zhang, L. Zou, J.-J. Zhu, A label-free cytosensor for the enhanced electrochemical detection of cancer cells using polydopamine-coated carbon nanotubes, Analyst 137 (2012) 1316-1318.

[34] S. Lhenry, Y.R. Leroux, P. Hapiot, Use of Catechol As Selective Redox Mediator in Scanning Electrochemical Microscopy Investigations, Anal. Chem. 84 (2012) 75187524.

[35] Y. Xie, B. Yan, H. Xu, J. Chen, Q. Liu, Y. Deng, H. Zeng, Highly regenerable musselinspired $\mathrm{Fe}_{2} \mathrm{O}_{3} @$ polydopamine- $\mathrm{Ag}$ core-shell microspheres as catalyst and adsorbent for methylene blue removal, ACS Appl. Mater. Interfaces 6 (2014) 8845-8852.

[36] S. Zhang, Y. Zhang, G. Bi, J. Liu, Z. Wang, Q. Xu, H. Xu, X. Li, Mussel-inspired polydopamine biopolymer decorated with magnetic nanoparticles for multiple pollutants removal, J. Hazard. Mater. 270 (2014) 27-34.

[37] Y. Yu, J.G. Shapter, R. Popelka-Filcoff, J.W. Bennett, A.V. Ellis, Copper removal using bio-inspired polydopamine coated natural zeolites, J. Hazard. Mater. 273 (2014) $174-182$.

[38] A. Ma, Y. Xie, J. Xu, H. Zeng, H. Xu, The significant impact of polydopamine on the catalytic performance of the carried $\mathrm{Au}$ nanoparticles, Chem. Commun. 51 (2015) $1469-1471$. 
[39] R.A. Zangmeister, T.A. Morris, M.J. Tarlov, Characterization of polydopamine thin films deposited at short times by autoxidation of dopamine, Langmuir 29 (2013) 86198628.

[40] Y. Liu, K. Ai, L. Lu, Polydopamine and its derivative materials: synthesis and promising applications in energy, environmental and biomedical fields, Chem. Rev. 114 (2014) 5057-5115.

[41] M. Sureshkumar, P.-N. Lee, C.-K. Lee, Stepwise assembly of multimetallic nanoparticles via self-polymerized polydopamine, J. Mater. Chem. 21 (2011) 1231612320 . 